\title{
Dedifferentiated liposarcomas: evaluation of the prognostic and therapeutic factors in the elderly patient
}

\author{
C Amodeo ${ }^{*}$, P Caglia', A Tracia, S Costa, V Russo, B Lucifora, L Borzi', E Zappulla \\ From de Senectute: Age and Health Forum \\ Catanzaro, Italy. 5-7 December 2009
}

\section{Background}

Liposarcomas (LPS) are rare tumors accounting approximately for $19 \%$ of adult soft-tissue tumors [1]. The most recent classification of the WHO divides liposarcomas into 3 main clinicopatological and genetic subtypes: myxoid/round cells liposarcoma, well differentiated / dedifferentiated liposarcoma and pleomorphic liposarcoma [2]. The importance of a total macroscopical resection to perform an oncologically correct operation is well known, so that it is often necessary to remove one or more adjoining organs with the purpose of reducing the risk of local secondary recurrences [3].

\section{Materials and methods}

We present the case of an 88-year-old woman with a large abdominal swelling. The TC of the abdomen shows the spleen moved upward (Figure. 1). The left hemiabdomen is filled by an expansive formation almost $20 \mathrm{~cm}$ wide in diameter, made partly of a solid component and partly cystic-like. The pancreas is totally against the gallbladder. It does not seem possible to remove the back wall of the spleen from the swelling. (Figure 2).

We decide to perform surgery. The neoplasia is in continuity with the tail of the pancreas, so a distal pancreasectomy and splenectomy is performed. Definitive histological examination: dedifferentiated liposarcoma of high degree.

\section{Results}

After surgical resection of the primitive liposarcoma, factors determining the probability of recurrence and

Department of Surgical Sciences, Transplantation and Advanced

Technologies - Surgical Oncology, University of Catania, Italy

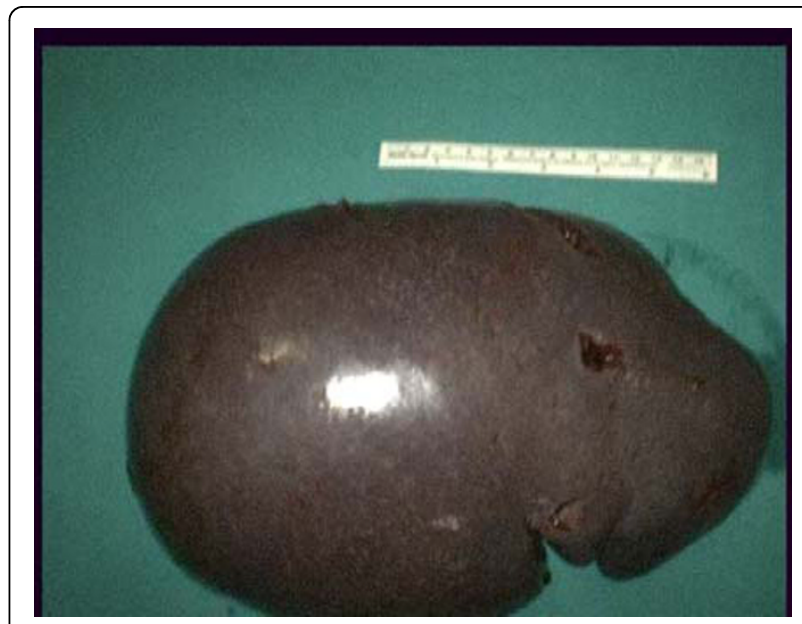

Figure 1

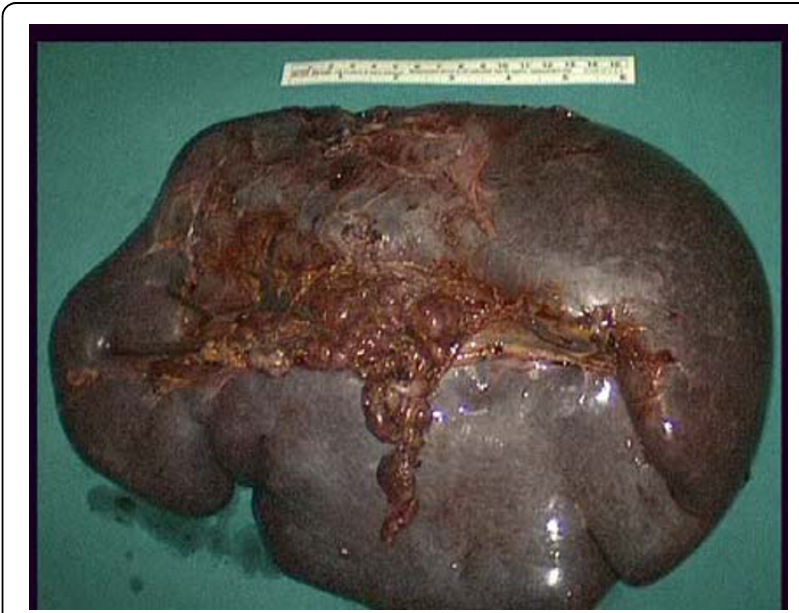

Figure 2 
survival are: histological type, the impossibility to perform a complete resection, the removal of adjoining organs and the advanced age [4].

\section{Conclusions}

In retroperitoneal and abdominal lesions surgical treatment remains the most important therapy because of the evident lack of benefit of chemotherapy and the impossibility to administer doses suitable of radiation without serious damag to the healthy tissues. Studies are in progress for the revaluation of intraoperative radiotherapy (IORT) and of preoperative chemotherapy.

Published: 19 May 2010

\section{References}

1. Gutierrez JC, Perez EA, Franceschi D, Moffat FL, Livingstone AS, Koniaris LG: Outcomes for soft-tissue sarcoma in 8249 cases from a large state cancer registry. Journal of surgical research 2007, 141:105-114.

2. Mussi C, Collini P, Miceli R, Barisella M, Mariani L, Fiore M, Casali PG, Gronchi A: The prognostic impact of dedifferentiation in retroperitoneal liposarcoma. Cancer 2008, 113:1657-65;7.

3. Singer Doglietto GB, Tortorelli AP, Papa V, Rosa F, Bossola M, Prete F, Covino M, Pacelli F: Giant retroperitoneal sarcomas: a single institution experience. World I Surg 2007, 31:1047-1054.

4. S, Antonescu CR, Riedel E, et al: Histological subtype and margin of resection predict pattern of recurrence and survival for retroperitoneal liposarcoma. Ann Surg 2003, 238(1):358-370.

doi:10.1186/1471-2318-10-S1-A1

Cite this article as: Amodeo et al:: Dedifferentiated liposarcomas: evaluation of the prognostic and therapeutic factors in the elderly patient. BMC Geriatrics 2010 10(Suppl 1):A1.

\section{Submit your next manuscript to BioMed Central} and take full advantage of:

- Convenient online submission

- Thorough peer review

- No space constraints or color figure charges

- Immediate publication on acceptance

- Inclusion in PubMed, CAS, Scopus and Google Scholar

- Research which is freely available for redistribution

Submit your manuscript at www.biomedcentral.com/submit 